Article

\title{
Scandium Doping Effect on a Layered Perovskite Cathode for Low-Temperature Solid Oxide Fuel Cells (LT-SOFCs)
}

\author{
Donghwi Jeong ${ }^{1}$, Junyoung Kim ${ }^{1,2}$, Ohhun Kwon ${ }^{1}$, Chaehyun Lim ${ }^{1}$, Sivaprakash Sengodan ${ }^{1, *}$, \\ Jeeyoung Shin ${ }^{3,4, *}$ and Guntae Kim ${ }^{1, *}$ \\ 1 Department of Energy Engineering, Ulsan National Institute of Science and Technology (UNIST), \\ Ulsan 44919, Korea; disilane@unist.ac.kr (D.J.); junokis@unist.ac.kr (J.K.); koh2311@unist.ac.kr (O.K.); \\ topyim001@unist.ac.kr (C.L.) \\ 2 Department of Chemistry, University of Liverpool, Liverpool L69 3BX, UK \\ 3 Division of Mechanical Systems Engineering, Sookmyung Women's University, Seoul 04310, Korea \\ 4 Institute of Advanced Materials and Systems, Sookmyung Women's University, Seoul 04310, Korea \\ * Correspondence: shiva05@unist.ac.kr (S.S.); jshin@sookmyung.ac.kr (J.S.); gtkim@unist.ac.kr (G.K.); \\ Tel.: +82-2-2077-7866 (J.S.); +82-52-217-2917 (G.K.)
}

Received: 22 October 2018; Accepted: 8 November 2018; Published: 11 November 2018

\begin{abstract}
Layered perovskite oxides are considered as promising cathode materials for the solid oxide fuel cell (SOFC) due to their high electronic/ionic conductivity and fast oxygen kinetics at low temperature. Many researchers have focused on further improving the electrochemical performance of the layered perovskite material by doping various metal ions into the B-site. Herein, we report that $\mathrm{Sc}^{3+}$ doping into the layered perovskite material, $\mathrm{PrBaCo}_{2} \mathrm{O}_{5+\delta}(\mathrm{PBCO})$, shows a positive effect of increasing electrochemical performances. We confirmed that $\mathrm{Sc}^{3+}$ doping could provide a favorable crystalline structure of layered perovskite for oxygen ion transfer in the lattice with improved Goldschmidt tolerance factor and specific free volume. Consequently, the $\mathrm{Sc}^{3+}$ doped $\mathrm{PBCO}$ exhibits a maximum power density of $0.73 \mathrm{~W} \mathrm{~cm}^{-2}$ at $500{ }^{\circ} \mathrm{C}, 1.3$ times higher than that of $\mathrm{PBCO}$. These results indicate that $\mathrm{Sc}^{3+}$ doping could effectively improve the electrochemical properties of the layered perovskite material, $\mathrm{PBCO}$.
\end{abstract}

Keywords: perovskite; electrochemistry; solid oxide fuel cells; cathode material

\section{Introduction}

The solid oxide fuel cell (SOFC) is an attractive eco-friendly energy conversion system because of its high energy conversion efficiency, fuel flexibility, and low emission of pollutants [1-8]. Recently, many studies have focused on developing low-temperature $\left(400-600{ }^{\circ} \mathrm{C}\right)$ SOFCs (LT-SOFCs) because the intermediate-to-high-operating temperature $\left(600-1000^{\circ} \mathrm{C}\right)$ causes critical issues, such as material degradation and expensive maintenance costs $[9,10]$. However, the low-operating temperature leads to high cathodic polarization due to the slow kinetics of oxygen ion transfer. In this respect, mixed ionic and electronic conductors (MIECs) have received great attention because of their high electrocatalytic activity for the oxygen reduction reaction (ORR), high electrical conductivities, fast surface exchange coefficient, and high oxygen diffusivity characteristics. Also, the ORR occurs not only at the triple phase boundary (TPB) but at the entire surface of the cathode (i.e., the two-phase boundary, 2PB), because oxygen anions can transport through the MIEC bulk [11].

Among MIECs, layered perovskites have been widely used for SOFC cathode material because of its exceptional electrochemical catalytic activity [12-16]. These layered perovskites have a general formula of $\mathrm{AA}^{\prime} \mathrm{B}_{2} \mathrm{O}_{5+\delta}$, where $\mathrm{A}, \mathrm{A}^{\prime}$, and $\mathrm{B}$ are trivalent lanthanide ion, alkaline earth metal, and 
a first-row transition metal, respectively. The layered perovskite consists of a stacking sequential layer of $\ldots\left|\mathrm{A}^{\prime} \mathrm{O}\right| \mathrm{BO}_{2}\left|\mathrm{AO}_{\delta}\right| \mathrm{BO}_{2} \mid \ldots$ along the $c$-axis $[4,10,17]$. This layered structure possesses a disorder-free channel for ion motion in the $\left|\mathrm{AO}_{\delta}\right|$ and $\left|\mathrm{BO}_{2}\right|$ planes that can provide fast oxygen-ion transport $[18,19]$.

Recently, many researchers have devoted efforts to further improving the electrochemical performance of the layered perovskite by substituting various metal ions [20-26]. For example, substituting constant-valence state metal ions (e.g., $\mathrm{Nb}^{5+}, \mathrm{Ta}^{5+}$, and $\mathrm{Ti}^{4+}$ ) into the perovskite could increase the ionic conductivity by reducing the lattice strain that occurs during the oxygen ion transport [27-30]. Especially, in the oxygen transport membrane system, it was reported that doping scandium into the perovskite-type oxide improves the electrochemical property by lowering the activation energy for oxygen ion transfer [31,32]. In this regard, the $\mathrm{Sc}^{3+}$ doped layered perovskite oxide is expected to exhibit a lower cathode polarization of the LT-SOFC.

The crystal structure along with the $\mathrm{A}$ and / or $\mathrm{B}$ site cations play a significant role in determining the electrical and ionic properties of $\mathrm{PrBaCO}_{2} \mathrm{O}_{5+\delta}$ (PBCO) perovskite oxides. Based on the literature data and experimental observations, several interesting relationships between the crystal structure, composition, and electrochemical properties have been established. In this regard, the critical radius for the oxide-ion transfer, unit cell free volume, and Goldschmidt tolerance factor $\left(t_{f}\right)$ are the key factors that govern the oxide ion conductivity in PBCO perovskite oxides [33-35]. Among those properties, the Goldschmidt tolerance factor is a useful indicator for evaluating distortion of the crystal structure [36,37]. A Sc ${ }^{3+}$ ion substitution into the layered perovskite material PBCO could provide a beneficial effect on the of lattice crystal structure. The Goldschmidt tolerance factor $\left(t_{f}\right)$ approaches 1 by substitution of $\mathrm{Sc}^{3+}$ in PBCO. Since the $\mathrm{t}_{\mathrm{f}}$ value of $\mathrm{PBCO}$ is 1.012 , it is possible to reduce the $\mathrm{t}_{\mathrm{f}}$ by doping the $\mathrm{B}$ site with an ion larger than the Co ion. In this regard, substituting a larger $\mathrm{Sc}^{3+}(0.75 \AA)$ ion with a smaller $\mathrm{Co}^{3+}{ }^{4+}(0.53-0.61 \AA)$ ion could converge $t_{\mathrm{f}}$ closer to 1 , which enables fast oxygen transport. [38,39]

In this study, we report the improvement of electrochemical performance by $\mathrm{Sc}^{3+}$ doping into the layered perovskite, $\mathrm{PBCO}$. To investigate the $\mathrm{Sc}^{3+}$ doping effect on $\mathrm{PBCO}$, we evaluated the structural characteristics, morphological properties, oxygen contents $(5+\delta)$, electrical and electrochemical properties of $\mathrm{PBCO}, \mathrm{PrBaCo}_{1.9} \mathrm{Sc}_{0.1} \mathrm{O}_{5+\delta}$ (PBCSc), and $\mathrm{Pr}_{0.5} \mathrm{Ba}_{0.5} \mathrm{Co}_{0.9} \mathrm{Sc}_{0.1} \mathrm{O}_{3-\delta}$ (SP-PBCSc).

\section{Materials and Methods}

$\mathrm{PrBaCo}_{2} \mathrm{O}_{5+\delta}$ (PBCO), $\mathrm{PrBaCo}_{1.9} \mathrm{Sc}_{0.1} \mathrm{O}_{5+\delta}$ (PBCSc) and $\mathrm{Pr}_{0.5} \mathrm{Ba}_{0.5} \mathrm{Co}_{0.9} \mathrm{Sc}_{0.1} \mathrm{O}_{3-\delta}$ (SP-PBCSc) oxides were synthesized through the Pechini method. Stoichiometric amounts of $\operatorname{Pr}\left(\mathrm{NO}_{3}\right)_{3} \cdot 6 \mathrm{H}_{2} \mathrm{O}$ (Aldrich, St. Louis, $\mathrm{MO}$, USA, $99.9 \%$, metal basis), $\mathrm{Ba}\left(\mathrm{NO}_{3}\right)_{2}$ (Aldrich, $\geq 99 \%$ ), $\mathrm{Co}\left(\mathrm{NO}_{3}\right)_{2} \cdot 6 \mathrm{H}_{2} \mathrm{O}$ (Aldrich, $\geq 98 \%$ ), $\mathrm{Sc}\left(\mathrm{NO}_{3}\right)_{3} \cdot \mathrm{xH}_{2} \mathrm{O}$ (Alfa Aesar, Haverhill, MA, USA, 99.9\%), and citric acid as chelate were dissolved in distilled water. After the proper amount of polyethylene glycol was completely dissolved, the solutions were heated to approximately $250^{\circ} \mathrm{C}$ in air until combustion to form a fine powder of the cathode materials. The resulting powders were calcined at $600^{\circ} \mathrm{C}$ for $4 \mathrm{~h}$ and ground with zirconia balls for $24 \mathrm{~h}$. Samples were pressed into a pellet and sintered at $1150^{\circ} \mathrm{C}$ for $6 \mathrm{~h}$ and $1200{ }^{\circ} \mathrm{C}$ for $4 \mathrm{~h}$ to prepare a dense pellet. The $\mathrm{Ce}_{0.9} \mathrm{Gd}_{0.1} \mathrm{O}_{2-\delta}$ (GDC) powder for the electrolyte and the NiO-GDC powder for the anode were synthesized using the glycine-nitrate process (GNP) with stoichiometric amounts of metal nitrates and glycine.

The crystalline structures of samples were determined by X-ray diffractometer (Rigaku diffractometer, $\mathrm{Cu} \mathrm{K} \alpha$ radiation). The Rietveld refinement using GSAS II program was used to analyze the crystal structures and lattice parameters of the samples. The high-resolution transmittance electron microscopy (HR TEM) images were obtained with a JEOL JEM 2100F at $200 \mathrm{kV}$. The microstructures of samples were investigated using a field emission scanning electron microscope (Nova Nano SEM, FEI, Hillsboro, OR, USA). The electrical conductivities of samples were determined by a four-terminal DC arrangement with a BioLogic Potentiostat from 100 to $800^{\circ} \mathrm{C}$. Thermogravimetric analysis (TGA) was performed using a thermogravimetric analyzer (SDT-Q600, TA Instruments, New Castle, DE, 
USA) from $100{ }^{\circ} \mathrm{C}$ to $900{ }^{\circ} \mathrm{C}$ with a heating/cooling rate of $2{ }^{\circ} \mathrm{C} \mathrm{min}^{-1}$ in air. Iodometric titration was performed to measure the oxygen contents at room temperature. The samples were dissolved in $\mathrm{HCl}$ under inert gas atmosphere to prevent the oxidation of the $\mathrm{I}^{-}$ions. The solution was titrated with sodium thiosulfate solution. Regarding the error of this analytic method, the standard deviation values of the samples were calculated.

Symmetric cells were used for the impedance spectroscopy measurement. The GDC powders were pressed into pellets and sintered at $1350{ }^{\circ} \mathrm{C}$ for $4 \mathrm{~h}$ in air to fabricate a dense electrolyte. Cathode slurries were painted onto both surfaces of the GDC electrolyte and heated at $950{ }^{\circ} \mathrm{C}$ for $4 \mathrm{~h}$. Ni-GDC anode-supported cells (cathode/GDC/Ni-GDC) were prepared using a drop-coating method. The $\mathrm{NiO}$ powder, GDC powder, and starch were mixed using ball-milling in ethanol for $24 \mathrm{~h}$. The mixed powders were pressed into pellets and fired at $800^{\circ} \mathrm{C}$ for $4 \mathrm{~h}$. Thin GDC electrolyte was prepared by a refined particle suspension coating technique. A GDC suspension was prepared by dispersing GDC powders (Aldrich) in a solvent with the proper amount of binder, then dispersant, and plasticizer at a ratio of 1:10. The GDC suspension was prepared by dispersing GDC powder in a solution of 2-butanone and ethanol with a small amount of polyvinyl butyral as a binder, then plasticizers such as polyalkylene glycol and butyl benzyl phthalate, and triethanolamine as a dispersant at a ratio of 1:10. The GDC suspension solution was drop-coated to the Ni-GDC anode support, followed by drying in air and co-sintering at $1400{ }^{\circ} \mathrm{C}$ for $5 \mathrm{~h}$. For the preparation of cathode slurry, all pre-calcined electrode powders were blended with an organic binder (Heraeus V006) to form slurries. The cathode slurries were screen-printed on the surface of the electrolyte with an active cathode area of $0.36 \mathrm{~cm}^{2}$.

For the electrochemical performance of symmetrical cells and single cell, Ag wires were attached to both electrodes using Ag paste. Ceramic adhesive (Aremco, Valley Cottage, NY, USA, Ceramabond 552) was used to fix the cells at the end of the alumina tube.

Impedance spectra of the symmetrical cell in the air were measured at $400-600{ }^{\circ} \mathrm{C}$ under open circuit voltage (OCV) in a frequency range of $1 \mathrm{mHz}$ to $500 \mathrm{kHz}$ with $10 \mathrm{mV}$ AC perturbation with curve fitting using software EC-lab. Impedance spectra of the samples were fitted to equivalent circuits. To determine the electrochemical performance of single cells, humidified $\mathrm{H}_{2}\left(3 \mathrm{vol} \% \mathrm{H}_{2} \mathrm{O}\right)$ was provided on the surface of the anode, and air was supplied to the cathode as oxidant. The single cell performances of cathodes were investigated at $400-550{ }^{\circ} \mathrm{C}$ using the BioLogic Potentiostat.

\section{Results and Discussion}

The crystal structures of $\operatorname{PrBaCO}_{2} \mathrm{O}_{5+\delta} \quad(\mathrm{PBCO}), \quad \mathrm{PrBaCo}_{1.9} \mathrm{Sc}_{0.1} \mathrm{O}_{5+\delta} \quad$ (PBCSc), and $\operatorname{Pr}_{0.5} \mathrm{Ba}_{0.5} \mathrm{Co}_{0.9} \mathrm{Sc}_{0.1} \mathrm{O}_{3-\delta}$ (SP-PBCSc) were confirmed by X-ray diffraction (XRD) analysis (Figure 1a). The XRD patterns show a single-phase layered perovskite structure without any detectable impurities for PBCO and PBCSc. The chemical compatibility between the cathodes and the GDC electrolyte was investigated with the mixture sintered at $950{ }^{\circ} \mathrm{C}$ for $4 \mathrm{~h}$ (Figure $1 \mathrm{~b}$ ). It revealed that there were no secondary reactions between the cathodes and GDC electrolyte. Figure 1c-e exhibits the Rietveld refinement profiles with the difference between the observed and calculate XRD. ( $R p=0.19,0.16$ and 0.17 for PBCO, PBCSc and SP-PBCSc, respectively.) Crystal structures and the calculated lattice parameters are summarized in Table 1. $\mathrm{PrBaCo}_{1.8} \mathrm{Sc}_{0.2} \mathrm{O}_{5+\delta}$ is labeled with SP-PBCSc because of its different crystal structure with $\operatorname{PrBaCo}_{1.8} \mathrm{Sc}_{0.2} \mathrm{O}_{5+\delta}$. The samples for $\mathrm{Sc}^{3+} \leq 0.1$ represent the layered perovskite phase. As shown in Table 1, PBCO shows an orthorhombic crystal structure with the Pmmm space group, while PBCSc shows a tetragonal crystal structure with $\mathrm{P} 4 / \mathrm{mmm}$ space group. PBCO and PBCSc show a layered perovskite phase, however, SP-PBCSc with higher $\mathrm{Sc}^{3+}$ substitution $\left(\mathrm{Sc}^{3+}=0.2\right)$ shows a simple perovskite cubic crystal structure with $\mathrm{Pm} \overline{3} \mathrm{~m}$ space group. From the high-resolution transmission electron microscopy (HRTEM) images of PBCO and PBCSc, A-site ordering layered structures were observed showing a weak additional spot in the fast-Fourier transformed pattern, which are indexed with (001) of layered double perovskite. (Figure S1a,b) Meanwhile, HR TEM image of SP-PBCSc (Figure S1c) shows the fast-Fourier transformed pattern indexed with (001) of cubic perovskite. 

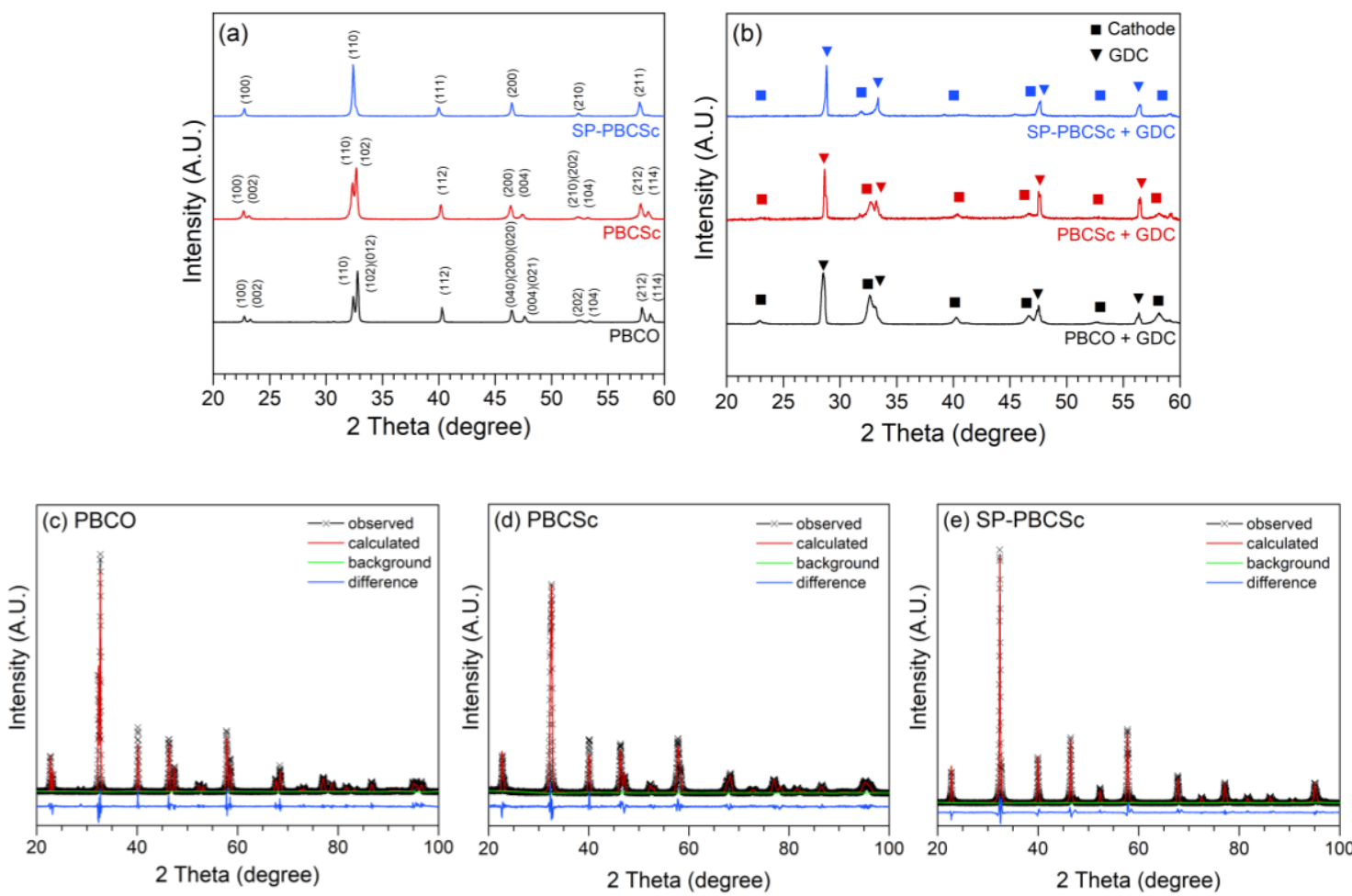

Figure 1. (a) X-ray diffraction (XRD) patterns of $\mathrm{PrBaCo}_{2} \mathrm{O}_{5+\delta}(\mathrm{PBCO}), \mathrm{PrBaCo}_{1.9} \mathrm{Sc}_{0.1} \mathrm{O}_{5+\delta}(\mathrm{PBCSc})$, and $\mathrm{Pr}_{0.5} \mathrm{Ba}_{0.5} \mathrm{Co}_{0.9} \mathrm{Sc}_{0.1} \mathrm{O}_{3-\delta}$ (SP-PBCSc). (b) The chemical compatibility between the cathode materials and $\mathrm{Ce}_{0.9} \mathrm{Gd}_{0.1} \mathrm{O}_{2-\delta}$ (GDC). Difference between the observed and calculated XRD profile of (c) PBCO, (d) PBCSc and (e) that of SP-PBCSc.

Table 1. Space group and lattice parameters of PBCO, PBCSc and SP-PBCSc.

\begin{tabular}{cccccccc}
\hline $\begin{array}{c}\text { Sc } \\
\text { Content }\end{array}$ & Cathode & $\begin{array}{c}\text { Space } \\
\text { Group }\end{array}$ & $\mathbf{a}(\AA)$ & $\mathbf{b}(\AA)$ & $\mathbf{c}(\AA)$ & $\begin{array}{c}\text { Unit Cell } \\
\text { Volume }\left(\AA^{3}\right)\end{array}$ & $\begin{array}{c}\text { Oxygen } \\
\text { Content }\end{array}$ \\
\hline 0 & $\mathrm{PrBaCo}_{2} \mathrm{O}_{5+\delta}$ & $P m m m$ & 3.91914 & 3.84016 & 7.85418 & 118.206 & 5.68 \\
0.1 & $\mathrm{PrBaCo}_{1.9} \mathrm{Sc}_{0.1} \mathrm{O}_{5+\delta}$ & $P 4 / m m m$ & 3.92141 & 3.92141 & 7.72105 & 118.730 & 5.64 \\
0.2 & $\mathrm{Pr}_{0.5} \mathrm{Ba}_{0.5} \mathrm{Co}_{0.9} \mathrm{Sc}_{0.1} \mathrm{O}_{3-\delta}$ & $P m \overline{3} m$ & 3.90801 & 3.90801 & 3.90801 & 59.685 & 2.80 \\
\hline
\end{tabular}

The microstructures of the PBCO and PBCSc were investigated using scanning electron microscopy (SEM) as presented in Figure 2. The similar microstructures of PBCO and PBCSc indicate that $\mathrm{Sc}^{3+}$ substitution does not affect the morphological property of the cathode materials. As shown in Figure 2c, a dense GDC electrolyte ( $10 \mu \mathrm{m}$ thick) and a porous PBCSc cathode $(\sim 25 \mu \mathrm{m}$ thick) are successfully fabricated without delamination between them.
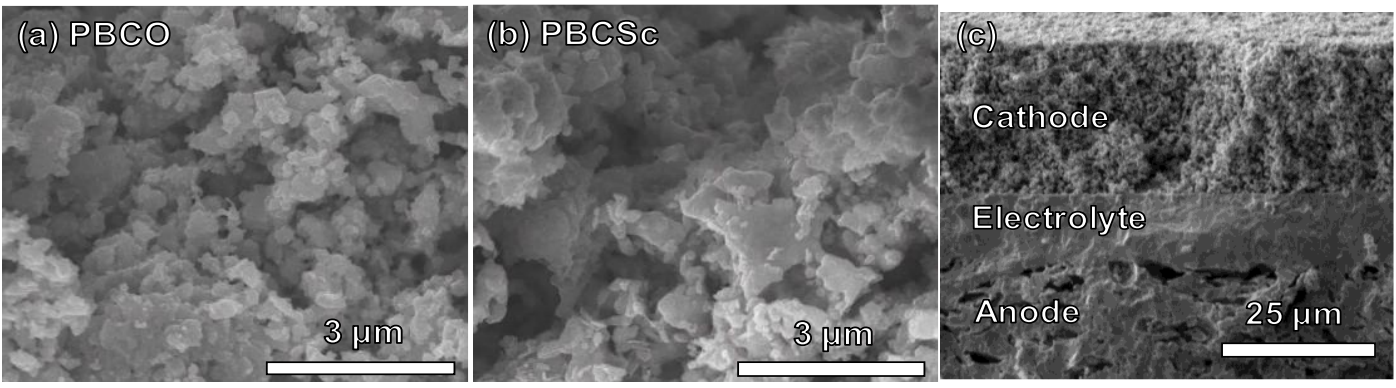

Figure 2. Scanning electron microscope image of (a) PBCO, (b) PBCSc and (c) a cross-section consisting of the GDC electrolyte with porous cathode and $\mathrm{Ni}-\mathrm{GDC}$ anode. 
Figure 3 a shows the temperature dependence of the oxygen non-stoichiometry for $\mathrm{PBCO}$ and PBCSc by thermogravimetric analysis (TGA) in air. The oxygen contents $(5+\delta)$ of samples at room temperature were determined by iodometric titration. Average $\delta$ values of $\mathrm{PBCO}$ and PBCSc at room temperature were $0.6833,0.6367$ with standard deviation values of $8.916 \times 10^{-3}$ and $9.251 \times 10^{-3}$, respectively. In the temperature range of $100-900{ }^{\circ} \mathrm{C}$, the $\mathrm{Sc}^{3+}$ substitution into $\mathrm{PBCO}$ leads to relatively decrease the oxygen content.

Figure $3 \mathrm{~b}$ presents the electrical conductivities of the samples at various temperatures. The electrical conductivities of all samples increase with decreasing temperature, implying a typical metallic behavior. All the samples show sufficient electrical conductivity values of 589, 503, and $344 \mathrm{~S} \mathrm{~cm}^{-1}$ for PBCO, PBCSc, and SP-PBCSc, respectively at $500{ }^{\circ} \mathrm{C}$, which are higher than the requirement for efficient SOFC operation $\left(>10 \mathrm{~S} \mathrm{~cm}^{-1}\right)$. PBCSc shows smaller electrical conductivity than $\mathrm{PBCO}$ due to disturbance of the electron conduction, which originated from the substitution of constant valance state $\mathrm{Sc}^{3+}$ ion for multivalent $\mathrm{Co}$ ion $[24,40,41]$. Substitution of the $\mathrm{Sc}^{3+}$ reduces the overlapping between multivalent $C o$ ion with the oxygen $2 p$ orbitals and decreases the electron transport between the multivalent cobalt cations, which is known as Zener double exchange.
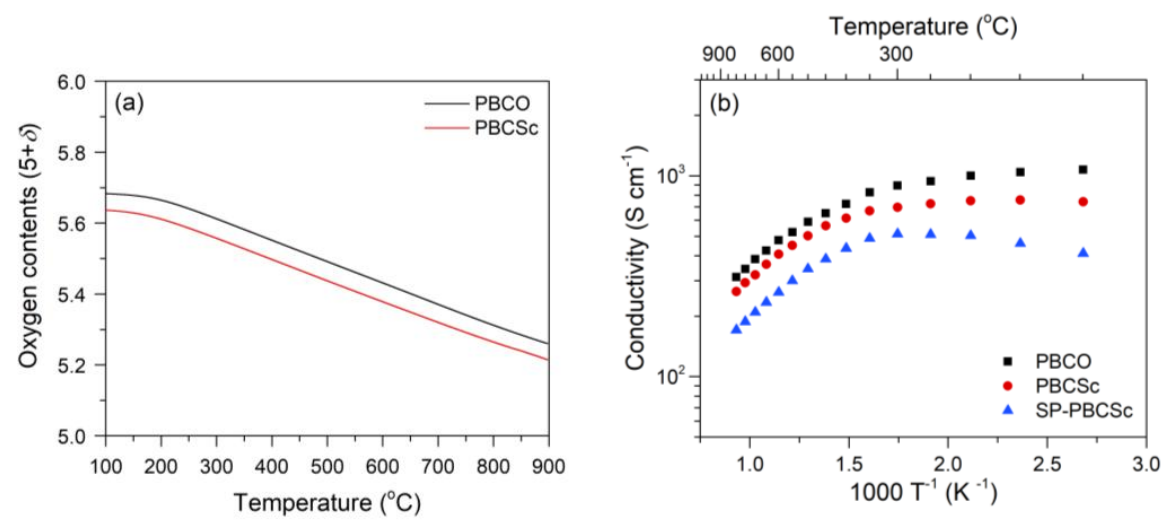

Figure 3. (a) Thermogravimetric analysis (TGA) and (b) electrical conductivity for the samples as a function of temperature in air.

The Goldschmidt tolerance factor is a useful indicator to determine the distortion of a unit cell structure, defined by the following equation;

$$
t_{f}=\frac{\left(r_{A}+r_{O}\right)}{\sqrt{\left(r_{B}+r_{O}\right)}}
$$

where $\mathrm{r}_{\mathrm{A}}, \mathrm{r}_{\mathrm{B}}$, and $\mathrm{r}_{\mathrm{O}}$ are the ionic radii of cation $\mathrm{A}$, cation $\mathrm{B}$, and oxygen, respectively. Figure 4 shows that the substitution of $\mathrm{Sc}^{3+}$ into $\mathrm{PBCO}$ can converge the Goldschmidt tolerance factor of PBCO near to 1 (e.g., from 1.012 to 1.006), implying that $\mathrm{Sc}^{3+}$ doping could reduce distortion of the perovskite structure and alleviate the local strain of the lattice.

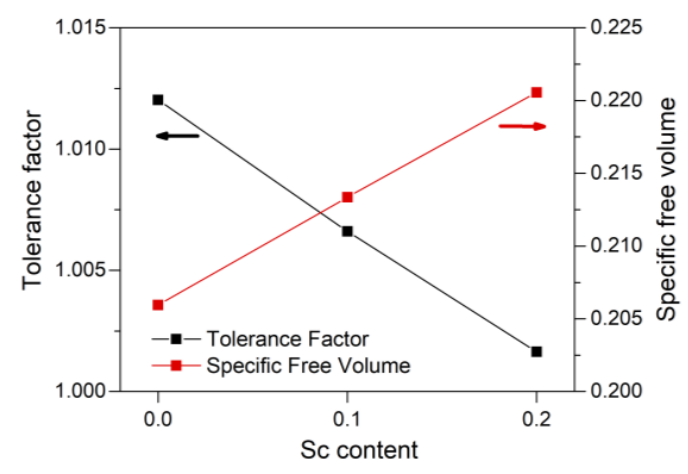

Figure 4. Goldschmidt tolerance factor and specific free volume of PBCO, PBCSc, and SP-PBCSc. 
The evaluation of free volume could be also a significant structural parameter to estimate electrochemical performance. Free volume is defined as the difference between the perovskite unit cell volume and the total volume occupied by the ions [36]. The large free volume could provide sufficient space for oxygen transport in the unit cell, resulting in the reduction of activation energy for oxygen diffusion [42]. Therefore, we calculated the specific free volume of PBCO and PBCSc, defined as follows;

$$
\text { (specific free volume) }=(\text { free volume }) /(\text { unit cell volume }) \text {, }
$$

As seen in Figure 4, PBCSc exhibits higher specific free volume, 0.213, than that of PBCO, 0.206, indicating that $\mathrm{PBCSc}$ can be considered as a more favorable structure for oxygen transfer due to larger free volume for oxygen migration than that of PBCO.

Figure 5a shows impedance spectroscopy to evaluate the electrocatalytic activities of samples. The area specific resistances (ASRs) were evaluated by alternating current (AC) impedance spectroscopy with GDC symmetrical cells in air. As can be expected from the favorable structural properties of PBCSc for oxygen anion transfer and ORR, (i.e., Goldschmidt tolerance factor and specific free volume) the PBCSc shows a lower ASR value of $0.44 \Omega \mathrm{cm}^{2}$ than that of PBCO $\left(0.58 \Omega \mathrm{cm}^{2}\right)$. Substitution of the $\mathrm{Sc}^{3+}$ ion into PBCO is a more effective method to reduce the impedance of the cathode material than several approaches recently reported to enhance the electrocatalytic activity of cathode materials. [43-45] Meanwhile, the ASR value of SP-PBCSc is increased due to its structural change to the cubic $\mathrm{Pm} \overline{3} \mathrm{~m}$ crystal structure. A similar result was observed in the A-site doped $\mathrm{PrBa}_{1-x} \mathrm{Sr}_{\mathrm{x}} \mathrm{Co}_{2} \mathrm{O}_{5+\delta}$ system; a phase transition was observed for higher Sr content (orthorhombic $\rightarrow$ tetragonal $\rightarrow$ cubic structure) [46]. According to the Adler-Lane-Steele (ALS) model [47], the ASR is related to oxygen kinetics, such as bulk diffusion $\left(D_{o}^{*}\right)$ and surface exchange $\left(k_{0}^{0}\right)$; this can be expressed as,

$$
\mathrm{R}_{\text {cathode }}=\frac{\mathrm{RT}}{2 \mathrm{~F}^{2}}\left[\frac{\tau}{(1-\varphi) \mathrm{Sc}_{0}^{2} \mathrm{D}_{\mathrm{o}}^{*} \mathrm{k}_{\mathrm{o}}^{\mathrm{o}}}\right]^{\frac{1}{2}}
$$

where $\varphi, S$, and $\tau$ are the porosity, surface area, and tortuosity, respectively. Assuming that the structural parameters of both PBCO and PBCSc are similar (porosity, cathode surface area, and tortuosity), high bulk diffusion and surface exchange lead to lower ASR values. Therefore, it can be explained that $\mathrm{Sc}^{3+}$ substitution results in the improvement of oxygen-related electrochemical properties (i.e., fast oxygen diffusion and high surface kinetics on the surface).

Total ASR values consist of the sum of the charge-transfer resistance $\left(R_{2}\right)$ and the non-charge transfer resistance $\left(R_{3}\right)$ [48]. $R_{2}$ is associated with the migration and diffusion of oxygen species from the triple phase boundary to the electrolyte, while $R_{3}$ is generally related to the non-charge transfer process (e.g., oxygen surface exchange and gas-phase diffusion on the surface of the electrode). The non-charge transfer resistance $\left(\mathrm{R}_{3}\right)$ of PBCSc is lower than that of PBCO, (Figure $5 b$ ) indicating that $\mathrm{Sc}^{3+}$ substitution considerably lowers non-charge transfer resistance $\left(\mathrm{R}_{3}\right)$ [25].

Arrhenius plots of the polarization resistances for PBCO, PBCSc, and SP-PBCSc are shown in Figure $5 c$. The activation energies determined by the slope of the Arrhenius plots are related to the oxygen kinetics of the cathode including the oxygen adsorption, dissociation, and diffusion behavior [14,49]. The activation energies $\left(E_{a}\right)$ are 102 and $96 \mathrm{~kJ} \mathrm{~mol}^{-1}$ for PBCO and PBCSc, respectively. This result matches well with other reports on the enhancement of oxygen surface exchange through partial substitution of $\mathrm{Sc}^{3+}$ [31,32].

Figure 6 presents the current-voltage (I-V) curves and corresponding power density curves for the cathode/GDC/Ni-GDC cell using humidified $\mathrm{H}_{2}$ and air, as a fuel and oxidant, respectively. As expected from the lower ASR value of PBCSc, PBCSc exhibits excellent maximum power densities of 1.3 and $0.73 \mathrm{~W} \mathrm{~cm}^{-2}$ at 550 and $500{ }^{\circ} \mathrm{C}$, respectively and these are $\sim 1.5$ times higher than those of PBCO. 

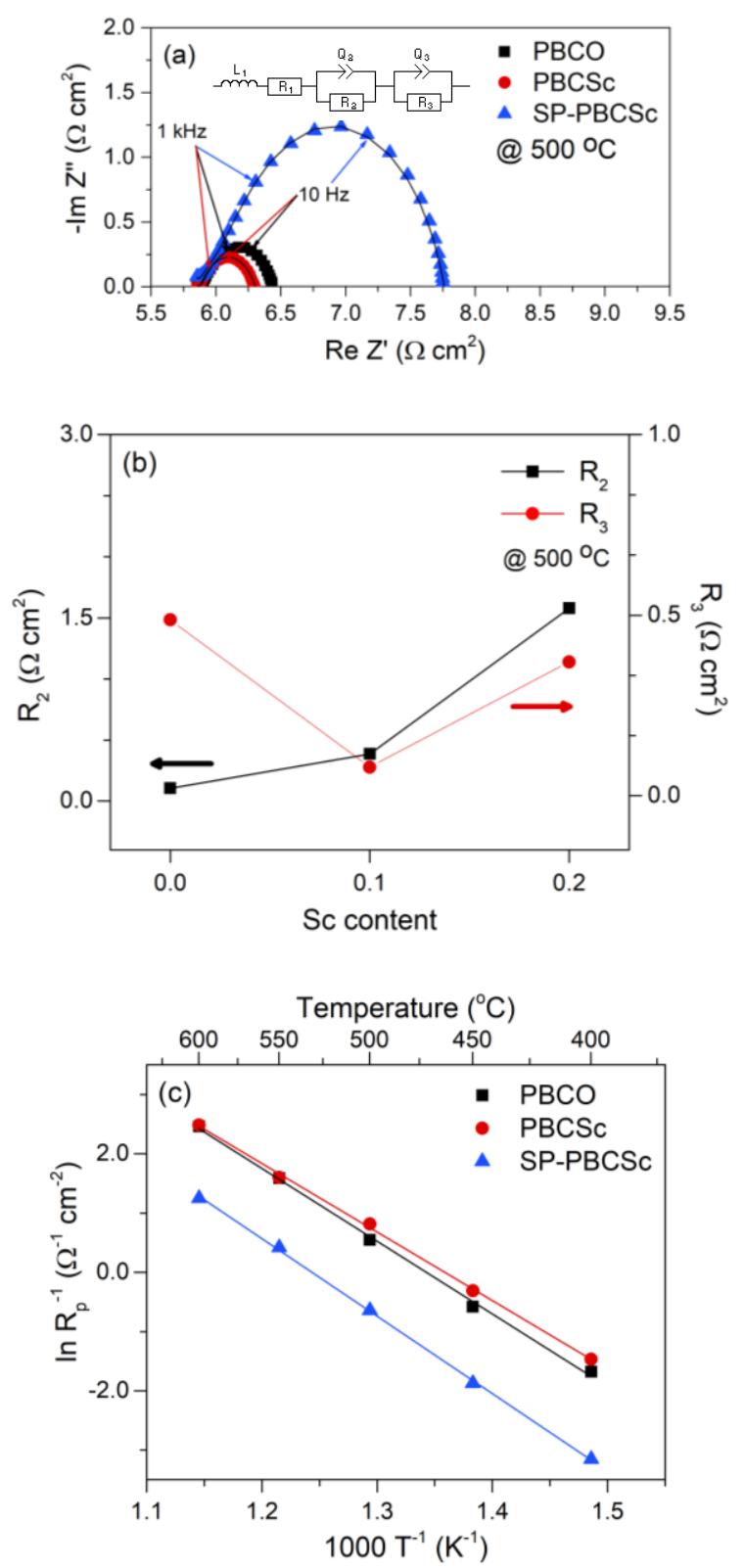

Figure 5. (a) Experimental and fitted impedance spectra of symmetrical cells with PBCO, PBCSc, and SP-PBCSc at $500{ }^{\circ} \mathrm{C}$. (b) Comparison of fitted charge-transfer resistance $\left(\mathrm{R}_{2}\right)$ and non-charge-transfer resistance $\left(\mathrm{R}_{3}\right)$ for samples at $500{ }^{\circ} \mathrm{C}$. (c) Arrhenius plot of the polarization resistances for samples.
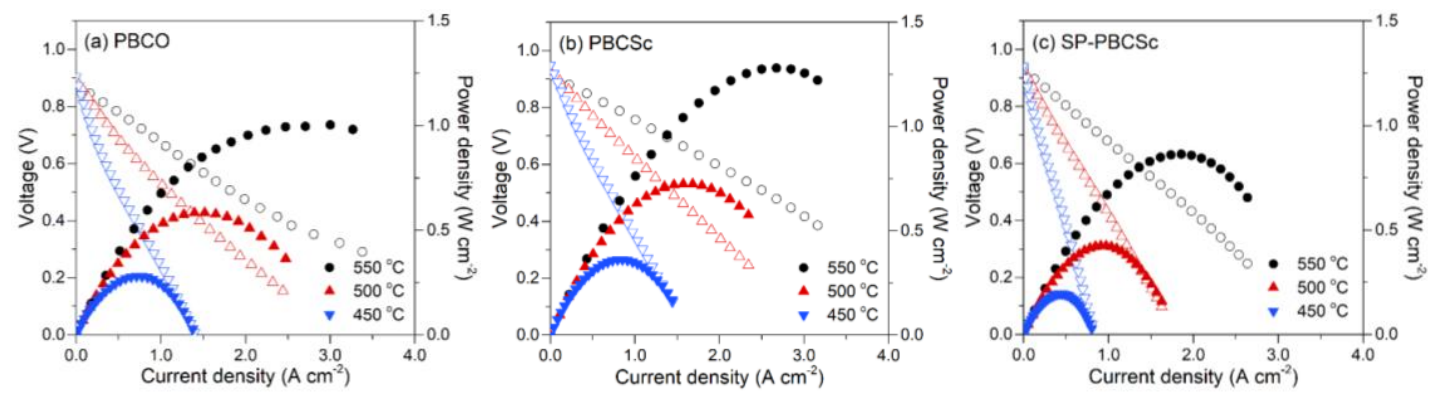

Figure 6. I-V and corresponding power density curves of single cells (Cathode/GDC/Ni-GDC) in a temperature range of 450 to $550{ }^{\circ} \mathrm{C}$ : (a) PBCO, (b) PBCSc, and (c) SP-PBCSc, respectively. 


\section{Conclusions}

In the present study, the scandium doping effect on $\mathrm{PrBaCo}_{2} \mathrm{O}_{5+\delta}$ (PBCO) was studied to improve the electrochemical performance of LT-SOFC by characterizing the structural, electrical, and electrochemical properties of $\mathrm{PBCO}$ and $\mathrm{PrBaCo}_{1.9} \mathrm{Sc}_{0.1} \mathrm{O}_{5+\delta}$ (PBCSc). The substitution of $\mathrm{Sc}^{3+}$ improves the electrochemical performance of $\mathrm{PBCO}$ by favoring structural properties related to $\mathrm{O}^{2-}$ diffusion and oxygen reduction reactions. Based on these favorable $\mathrm{Sc}^{3+}$ doping effects, the PBCSc cathode presents a low polarization resistance $\left(0.44 \Omega \mathrm{cm}^{2}\right)$ at $500{ }^{\circ} \mathrm{C}$ with a maximum power density of $0.73 \mathrm{~W} \mathrm{~cm}^{-2}$ which is 1.3 times higher than that of PBCO. Consequently, these results imply that the substitution of $\mathrm{Sc}^{3+}$ into the PBCO could effectively enhance the cathodic electrochemical performance of low-temperature SOFC.

Supplementary Materials: The following are available online at http:/ / www.mdpi.com/2076-3417/8/11/2217/ s1, Figure S1: The high-resolution transmission electron microscopy (HRTEM) images of (a) PBCO, (b) PBCSc, and (c) SP-PBCSc, Figure S2: Impedance spectra of single cells (Cathode/GDC/Ni-GDC) in a temperature range of 450 to $550^{\circ} \mathrm{C}$ : (a) PBCO, (b) PBCSc and (c) SP-PBCSc, respectively.

Author Contributions: Formal analysis and investigation, D.J.; Rietveld refinement assistance, C.L.; TEM image analysis, O.K.; writing—original draft preparation, D.J., and J.K.; writing—review and editing, S.S., J.S., and G.K.; supervision, G.K.

Funding: This work was supported by the Korea Institute of Energy Technology Evaluation and Planning (KETEP) and the Ministry of Trade, Industry \& Energy (MOTIE) of the Republic of Korea (No. 20173020032120).

Conflicts of Interest: The authors declare no conflict of interest.

\section{References}

1. Winter, M.; Brodd, R.J. What are batteries, fuel cells, and supercapacitors? Chem. Rev. 2004, 104, 4245-4270. [CrossRef] [PubMed]

2. Sengodan, S.; Choi, S.; Jun, A.; Shin, T.H.; Ju, Y.-W.; Jeong, H.Y.; Shin, J.; Irvine, J.T.S.; Kim, G. Layered oxygen-deficient double perovskite as an efficient and stable anode for direct hydrocarbon solid oxide fuel cells. Nat. Mater. 2015, 14, 205-209. [CrossRef] [PubMed]

3. Mogensen, M.; Jensen, K.V.; Jorgensen, M.J.; Primdahl, S. Progress in understanding SOFC electrodes. Solid State Ion. 2002, 150, 123-129. [CrossRef]

4. Choi, S.; Yoo, S.; Kim, J.; Park, S.; Jun, A.; Sengodan, S.; Kim, J.; Shin, J.; Jeong, H.Y.; Choi, Y.; et al. Highly efficient and robust cathode materials for low-temperature solid oxide fuel cells: $\operatorname{PrBa}_{0.5} \mathrm{Sr}_{0.5} \mathrm{Co}_{2-\mathrm{x}} \mathrm{Fe}_{\mathrm{x}} \mathrm{O}_{5+\delta}$. Sci. Rep. 2013, 3, 2426. [CrossRef] [PubMed]

5. Park, S.; Vohs, J.M.; Gorte, R.J. Direct oxidation of hydrocarbons in a solid-oxide fuel cell. Nature 2000, 404, 265-267. [CrossRef] [PubMed]

6. Tao, S.; Irvine, J.T.S. A redox-stable efficient anode for solid-oxide fuel cells. Nat. Mater. 2003, 2, $320-323$. [CrossRef] [PubMed]

7. Minh, N.Q. Ceramic Fuel Cells. J. Am. Ceram. Soc. 1993, 76, 563-588. [CrossRef]

8. Gross, M.D.; Vohs, J.M.; Gorte, R.J. Recent progress in SOFC anodes for direct utilization of hydrocarbons. J. Mater. Chem. 2007, 17, 3071-3077. [CrossRef]

9. Wachsman, E.D.; Lee, K.T. Lowering the Temperature of Solid Oxide Fuel Cells. Science 2011, 334, 935-939. [CrossRef] [PubMed]

10. Yoo, S.; Jun, A.; Ju, Y.-W.; Odkhuu, D.; Hyodo, J.; Jeong, H.Y.; Park, N.; Shin, J.; Ishihara, T.; Kim, G. Development of double-perovskite compounds as cathode materials for low-temperature solid oxide fuel cells. Angew. Chem. Int. Ed. 2014, 53, 13064-13067. [CrossRef] [PubMed]

11. Jung, W.; Gu, K.L.; Choi, Y.; Haile, S.M. Robust nanostructures with exceptionally high electrochemical reaction activity for high temperature fuel cell electrodes. Energy Environ. Sci. 2014, 7, 1685-1692. [CrossRef]

12. Kim, G.; Wang, S.; Jacobson, A.J.; Yuan, Z.; Donner, W.; Chen, C.L.; Reimus, L.; Brodersen, P.; Mims, C.A. Oxygen exchange kinetics of epitaxial $\mathrm{PrBaCo}_{2} \mathrm{O}_{5+\delta}$ thin films. Appl. Phys. Lett. 2006, 88, 024103. [CrossRef]

13. Jacobson, A.J. Materials for Solid Oxide Fuel Cells. Chem. Mater. 2010, 22, 660-674. [CrossRef] 
14. Kim, G.; Wang, S.; Jacobson, A.J.; Reimus, L.; Brodersen, P.; Mims, C.A. Rapid oxygen ion diffusion and surface exchange kinetics in $\mathrm{PrBaCO}_{2} \mathrm{O}_{5+x}$ with a perovskite related structure and ordered A cations. J. Mater. Chem. 2007, 17, 2500-2505. [CrossRef]

15. Tarancon, A.; Skinner, S.J.; Chater, R.J.; Hernandez-Ramirez, F.; Kilner, J.A. Layered perovskites as promising cathodes for intermediate temperature solid oxide fuel cells. J. Mater. Chem. 2007, 17, 3175-3181. [CrossRef]

16. Kim, J.-H.; Manthiram, A. Layered $\mathrm{LnBaCo}_{2} \mathrm{O}_{5+\delta}$ Perovskite Cathodes for Solid Oxide Fuel Cells: An Overview and Perspective. J. Mater. Chem. A 2015, 3, 24195-24210. [CrossRef]

17. Jeong, D.; Jun, A.; Ju, Y.-W.; Hyodo, J.; Shin, J.; Ishihara, T.; Lim, T.-H.; Kim, G. Structural, Electrical, and Electrochemical Characteristics of $\mathrm{LnBa}_{0.5} \mathrm{Sr}_{0.5} \mathrm{Co}_{1.5} \mathrm{Fe}_{0.5} \mathrm{O}_{5+\delta}(\mathrm{Ln}=\mathrm{Pr}, \mathrm{Sm}, \mathrm{Gd})$ as Cathode Materials in Intermediate-Temperature Solid Oxide Fuel Cells. Energy Technol. 2017, 5, 1337-1343. [CrossRef]

18. Taskin, A.A.; Lavrov, A.N.; Ando, Y. Achieving fast oxygen diffusion in perovskites by cation ordering. Appl. Phys. Lett. 2005, 86, 091910. [CrossRef]

19. Taskin, A.A.; Lavrov, A.N.; Ando, Y. Fast oxygen diffusion in A-site ordered perovskites. Prog. Solid State Chem. 2007, 35, 481-490. [CrossRef]

20. Yoo, S.; Shin, J.; Kim, G. Thermodynamic and Electrical Properties of Layered Perovskite $\mathrm{NdBaCo}_{2-\mathrm{x}} \mathrm{Fe}_{\mathrm{x}} \mathrm{O}_{5+\delta}$ - YSZ $(x=0,1)$ Composites for Intermediate Temperature SOFC Cathodes. J. Electrochem. Soc. 2011, 158, B632-B638. [CrossRef]

21. Yoo, S.; Lim, T.-H.; Shin, J.; Kim, G. Comparative characterization of thermodynamic, electrical, and electrochemical properties of $\mathrm{Sm}_{0.5} \mathrm{Sr}_{0.5} \mathrm{Co}_{1-x} \mathrm{Nb}_{\mathrm{x}} \mathrm{O}_{3-\delta}(\mathrm{x}=0,0.05$, and 0.1$)$ as cathode materials in intermediate temperature solid oxide fuel cells. J. Power Sources 2013, 226, 1-7. [CrossRef]

22. Kim, J.; Choi, S.; Park, S.; Kim, C.; Shin, J.; Kim, G. Effect of Mn on the electrochemical properties of a layered perovskite $\mathrm{NdBa}_{0.5} \mathrm{Sr}_{0.5} \mathrm{Co}_{2-\mathrm{x}} \mathrm{Mn}_{\mathrm{x}} \mathrm{O}_{5+\delta}(\mathrm{x}=0,0.25$, and 0.5$)$ for intermediate-temperature solid oxide fuel cells. Electrochim. Acta 2013, 112, 712-718. [CrossRef]

23. Jun, A.; Lim, T.-H.; Shin, J.; Kim, G. Electrochemical properties of B-site Ni doped layered perovskite cathodes for IT-SOFCs. Int. J. Hydrogen Energy 2014, 39, 20791-20798. [CrossRef]

24. Kim, J.; Jun, A.; Shin, J.; Kim, G. Effect of Fe Doping on Layered $\mathrm{GdBa}_{0.5} \mathrm{Sr}_{0.5} \mathrm{Co}_{2} \mathrm{O}_{5+\delta}$ Perovskite Cathodes for Intermediate Temperature Solid Oxide Fuel Cells. J. Am. Ceram. Soc. 2014, 97, 651-656. [CrossRef]

25. Jun, A.; Yoo, S.; Ju, Y.-W.; Hyodo, J.; Choi, S.; Jeong, H.Y.; Shin, J.; Ishihara, T.; Lim, T.-H.; Kim, G. Correlation between fast oxygen kinetics and enhanced performance in Fe doped layered perovskite cathodes for solid oxide fuel cells. J. Mater. Chem. A 2015, 3, 15082-15090. [CrossRef]

26. Jun, A.; Shin, J.; Kim, G. High redox and performance stability of layered $\mathrm{SmBa}_{0.5} \mathrm{Sr}_{0.5} \mathrm{Co}_{1.5} \mathrm{Cu}_{0.5} \mathrm{O}_{5+\delta}$ perovskite cathodes for intermediate-temperature solid oxide fuel cells. Phys. Chem. Chem. Phys. 2013, 15, 19906-19912. [CrossRef] [PubMed]

27. Chen, X.; Huang, L.; Wei, Y.; Wang, H. Tantalum stabilized $\mathrm{SrCoO}_{3-\delta}$ perovskite membrane for oxygen separation. J. Membr. Sci. 2011, 368, 159-164. [CrossRef]

28. Zhang, K.; Ran, R.; Ge, L.; Shao, Z.; Jin, W.; Xu, N. Systematic investigation on new $\mathrm{SrCo}_{1-\mathrm{y}} \mathrm{Nb}_{\mathrm{y}} \mathrm{O}_{3-\delta}$ ceramic membranes with high oxygen semi-permeability. J. Membr. Sci. 2008, 323, 436-443. [CrossRef]

29. Li, X.; Jiang, X.; Xu, H.; Xu, Q.; Jiang, L.; Shi, Y.; Zhang, Q. Scandium-doped $\mathrm{PrBaCo}_{2-\mathrm{x}} \mathrm{Sc}_{\mathrm{x}} \mathrm{O}_{6-\delta}$ oxides as cathod material for intermediate-temperature solid oxide fuel cells. Int. J. Hydrogen Energy 2013, 38, 12035-12042. [CrossRef]

30. Shen, Y.; Wang, F.; Ma, X.; He, T. $\mathrm{SrCo}_{1-y} \mathrm{Ti}_{\mathrm{y}} \mathrm{O}_{3-\delta}$ as potential cathode materials for intermediate-temperature solid oxide fuel cells. J. Power Sources 2011, 196, 7420-7425. [CrossRef]

31. Chen, D.; Chen, C.; Zhang, Z.; Baiyee, Z.M.; Ciucci, F.; Shao, Z. Compositional engineering of perovskite oxides for highly efficient oxygen reduction reactions. ACS Appl. Mater. Interfaces 2015, 7, 8562-8571. [CrossRef] [PubMed]

32. Yin, Y.-M.; Xiong, M.-W.; Yang, N.-T.; Tong, Z.; Guo, Y.-Q.; Ma, Z.-F.; Sun, E.; Yamanis, J.; Jing, B.-Y. Investigation on thermal, electrical, and electrochemical properties of scandium-doped $\mathrm{Pr}_{0.6} \mathrm{Sr}_{0.4}\left(\mathrm{Co}_{0.2} \mathrm{Fe}_{0.8}\right)_{(1-\mathrm{x})} \mathrm{Sc}_{\mathrm{x}} \mathrm{O}_{3-\delta}$ as cathode for IT-SOFC. Int. J. Hydrogen Energy 2011, 36, 3989-3996. [CrossRef]

33. Tsuji, T.; Ohashi, Y.; Yamamura, Y. Effect of ionic radius on electrical conductivity of doped $\mathrm{SmAlO}_{3}$ perovskite oxide. Solid State Ion. 2002, 154-155, 541-546. [CrossRef]

34. Lybye, D.; Poulsen, F.W.; Mogensen, M. Conductivity of A- and B-site doped $\mathrm{LaAlO}_{3}, \mathrm{LaGaO}_{3}, \mathrm{LaScO}_{3}$ and $\mathrm{LaInO}_{3}$ perovskites. Solid State Ion. 2000, 128, 91-103. [CrossRef] 
35. Nomura, K.; Tanase, S. Electrical conduction behavior in $\left(\mathrm{La}_{0.9} \mathrm{Sr}_{0.1}\right) \mathrm{M}_{\mathrm{III}} \mathrm{O}_{3-\delta}\left(\mathrm{M}_{\mathrm{III}}=\mathrm{Al}, \mathrm{Ga}, \mathrm{Sc}\right.$, In, and $\left.\mathrm{Lu}\right)$ perovskites. Solid State Ion. 1997, 98, 229-236. [CrossRef]

36. Hayashi, H.; Inaba, H.; Matsuyama, M.; Lan, N.G.; Dokiya, M.; Tagawa, H. Structural consideration on the ionic conductivity of perovskite-type oxides. Solid State Ion. 1999, 122, 1-15. [CrossRef]

37. Švarcová, S.; Wiik, K.; Tolchard, J.; Bouwmeester, H.J.M.; Grande, T. Structural instability of cubic perovskite $\mathrm{Ba}_{\mathrm{x}} \mathrm{Sr}_{1-\mathrm{x}} \mathrm{Co}_{1-\mathrm{y}} \mathrm{Fe}_{\mathrm{y}} \mathrm{O}_{3-\delta}$. Solid State Ion. 2008, 178, 1787-1791. [CrossRef]

38. Jung, J.-I.; Edwards, D.D. X-ray photoelectron (XPS) and Diffuse Reflectance Infra Fourier Transformation (DRIFT) study of $\mathrm{Ba}_{0.5} \mathrm{Sr}_{0.5} \mathrm{Co}_{\mathrm{X}} \mathrm{Fe}_{1-\mathrm{x}} \mathrm{O}_{3-\delta}$ (BSCF: $\mathrm{X}=0-0.8$ ) ceramics. J. Solid State Chem. 2011, 184, 2238-2243. [CrossRef]

39. Shannon, R.D. Revised effective ionic radii and systematic studies of interatomic distances in halides and chalcogenides. Acta Crystallogr. Sect. A 1976, 32, 751-767. [CrossRef]

40. Sengodan, S.; Ahn, S.; Shin, J.; Kim, G. Oxidation-reduction behavior of $\mathrm{La}_{0.8} \mathrm{Sr}_{0.2} \mathrm{Sc}_{\mathrm{y}} \mathrm{Mn}_{1-\mathrm{y}} \mathrm{O}_{3 \pm \delta}(\mathrm{y}=0.2,0.3$, 0.4): Defect structure, thermodynamic and electrical properties. Solid State Ion. 2012, 228, 25-31. [CrossRef]

41. McIntosh, S.; Gorte, R.J. Direct Hydrocarbon Solid Oxide Fuel Cells. Chem. Rev. 2004, 104, 4845-4866. [CrossRef] [PubMed]

42. Cook, R.L.; Sammells, A.F. On the systematic selection of perovskite solid electrolytes for intermediate temperature fuel cells. Solid State Ion. 1991, 45, 311-321. [CrossRef]

43. dos Santos-Gómez, L.; Porras-Vázquez, J.M.; Losilla, E.R.; Marrero-López, D. Improving the efficiency of layered perovskite cathodes by microstructural optimization. J. Mater. Chem. A 2017, 5, 7896-7904. [CrossRef]

44. Chen, D.; Ran, R.; Shao, Z. Assessment of $\mathrm{PrBaCo}_{2} \mathrm{O}_{5+\delta}+\mathrm{Sm}_{0.2} \mathrm{Ce}_{0.8} \mathrm{O}_{1.9}$ composites prepared by physical mixing as electrodes of solid oxide fuel cells. J. Power Sources 2010, 195, 7187-7195. [CrossRef]

45. Chen, D.; Ran, R.; Shao, Z. Effect of firing temperature on the microstructure and performance of $\mathrm{PrBaCo}_{2} \mathrm{O}_{5+\delta}$ cathodes on $\mathrm{Sm}_{0.2} \mathrm{Ce}_{0.8} \mathrm{O}_{1.9}$ electrolytes fabricated by spray deposition-firing processes. J. Power Sources 2010, 195, 4667-4675. [CrossRef]

46. Park, S.; Choi, S.; Kim, J.; Shin, J.; Kim, G. Strontium Doping Effect on High-Performance $\operatorname{PrBa}_{1-\mathrm{x}} \mathrm{Sr}_{\mathrm{x}} \mathrm{Co}_{2} \mathrm{O}_{5+\delta}$ as a Cathode Material for IT-SOFCs. ECS Electrochem. Lett. 2012, 1, F29-F32. [CrossRef]

47. Adler, S.B.; Lane, J.A.; Steele, B.C.H. Electrode kinetics of porous mixed-conducting oxygen electrodes. J. Electrochem. Soc. 1996, 143, 3554-3564. [CrossRef]

48. Bevilacqua, M.; Montini, T.; Tavagnacco, C.; Fonda, E.; Fornasiero, P.; Graziani, M. Preparation, Characterization, and Electrochemical Properties of Pure and Composite $\mathrm{LaNi}_{0.6} \mathrm{Fe}_{0.4} \mathrm{O}_{3}$-Based Cathodes for IT-SOFC. Chem. Mater. 2007, 19, 5926-5936. [CrossRef]

49. Jun, A.; Kim, J.; Shin, J.; Kim, G. Optimization of Sr content in layered $\mathrm{SmBa}_{1-\mathrm{x}} \mathrm{Sr}_{\mathrm{x}} \mathrm{Co}_{2} \mathrm{O}_{5+\delta}$ perovskite cathodes for intermediate-temperature solid oxide fuel cells. Int. J. Hydrogen Energy 2012, 37, 18381-18388. [CrossRef]

(c) 2018 by the authors. Licensee MDPI, Basel, Switzerland. This article is an open access article distributed under the terms and conditions of the Creative Commons Attribution (CC BY) license (http://creativecommons.org/licenses/by/4.0/). 